\title{
NOTAS GRAMSCIANAS: GOLPE DE ESTADO E LUTA DE CLASSES NO BRASIL DO SÉCULO XXI
}

Marcelo Lira Silva ${ }^{1}$

RESUMO: Buscar-se-á desenvolver ao longo desse artigo a tese de que o Golpe de Estado soft no Brasil de 2016, de tipo Parlamentar-Judicial-Midiático, aprofundou a agenda neoliberal-flexível, fundamentada e estruturada no binômio modernização-conservação. Entretanto, devido a particularidade do processo de formação social brasileira, forjada a partir de uma revolução passiva (1928-1978), a agenda da modernização vem acompanhada pelo binômio modernização-conservação, no qual o elemento conservação impõe-se enquanto determinação histórico-social fundamental de condução da modernização. Trata-se de resgatar as chaves de leitura do pensador italiano Antonio Gramsci, como forma de construir as mediações e tentativas de construções de entendimento acerca do Brasil do século XXI.

Palavras-chave: Revolução passiva. Transformismo. Intelectualidade.

\section{GRAMSCIAN NOTES: STATE SWATCH AND CLASS FIGHT IN BRAZIL OF THE XXI CENTURY.}

ABSTRACT: It will be sought to develop throughout this article the thesis that the soft coup d'état in Brazil of 2016, of the type of Parliamentary-Judicial-Mediatic, deepened the neoliberal-flexible agenda, grounded and structured in the binomial modernizationconservation. However, due to the peculiarity of the process of Brazilian social formation, forged from a passive revolution (1928-1978), the modernization agenda is accompanied by the binomial modernization-conservation, in which the element of conservation is imposed as a historical-social determination modernization. It is about recovering the keys of reading of the Italian thinker Antonio Gramsci, as a way of constructing the mediations and attempts of constructions of understanding about Brazil of the 21st century.

Keywords: Passive revolution. Transformism. Intellectuality.

\footnotetext{
${ }^{1}$ Cientista Social e Filósofo (UNESP/Campus Marília). Mestre em Sociologia (UNESP/Campus Araraquara). Doutorado em Ciências Sociais (UNESP/Campus Marília). Pós-Doutorado em História (UFG/Faculdade de História). Professor Substituto de Ciências Sociais e Relações Internacionais (UNESP/ de 2010 a 2014). Professor Efetivo de Sociologia do Instituto Federal de Educação, Ciência e Tecnologia de Goiás/Campus Goiânia, desde abril de 2014. Endereço eletrônico: marcelo.silva@ifg.edu.br.
} 


\section{NOTAS GRAMSCIANAS: GOLPE DEL ESTADO Y LUCHA DE CLASES EN BRASIL DEL SIGLO XXI.}

RESUMEN: Se buscará desarrollar a lo largo de este artículo la tesis de que el Golpe de Estado soft en Brasil de 2016, de tipo Parlamentario-Judicial-Midiático, profundizó la agenda neoliberal-flexible, fundamentada y estructurada en el binomio modernización-conservación. Sin embargo, debido a la particularidad del proceso de formación social brasileña, forjada a partir de una revolución pasiva (1928-1978), la agenda de la modernización viene acompañada por el binomio modernización-conservación, en el cual el elemento conservación se impone en cuanto determinación histórico-social fundamental de la conducción de la modernización. Se trata de rescatar las claves de lectura del pensador italiano Antonio Gramsci, como forma de construir las mediaciones e intentos de construcciones de entendimiento acerca del Brasil del siglo XXI.

Palabras clave: Revolución pasiva. Transformismo. Intelectualidad.

\section{Introdução}

A formação social brasileira desenvolveu-se ontologicamente enquanto uma particularidade capitalista, ou seja, estruturou-se a partir de uma burguesia agrárioexportadora, fundamentada na acumulação originária do capital agrário-exportador e estruturada socialmente no escravagismo. Nesse sentido, o processo de emancipação política do Brasil, ou seja, a constituição do Estado brasileiro passou pela crise e dissolução do sistema colonial, a partir da qual se forjou um tipo particular de classes dominantes que forjaram um Estado sem uma nação. Trata-se da constituição de um tipo de capitalismo hipertardio, dependente e associado ao epicentro do capitalismo mundial, de tal forma que as classes dominantes brasileiras constituíram-se a partir do desenvolvimento e da difusão de um pensamento eclético, enraizado na tessitura social brasileira enquanto ideologia conservadora de viés conciliatório. Devido sua incapacidade de fundar-se enquanto classe dominante autônoma, constituída a partir de um projeto nacional de desenvolvimento próprio, e, portanto, de impossibilidade de competitividade no mercado internacional, as classes dominantes brasileiras criaram um tipo particular de bonapartismo-colonial, marcado pelo exclusivismo político; e, consequentemente, pela não admissão de qualquer tipo de participação e representatividade das classes trabalhadoras e demais classes subalternas nos processos decisórios do país. O tipo particular de desenvolvimento do capitalismo brasileiro forjou uma classe dominante autocrática, que pela via da revolução passiva, fortemente marcada pelo exclusivismo político passou a impor à sociedade brasileira um tipo particular de dominação fundamentada em Golpes de Estado recorrentes, na criminalização das frágeis 
organizações autônomas das classes trabalhadoras e demais classes subalternas, e, no encarceramento e/ou extermínio físico de suas principais lideranças. Nesse sentido, partir-se-á de tal fundamentação para a construção de um possível entendimento acerca do processo que culminou no Golpe de Estado soft, de tipo Parlamentar-Judicial-Midiático no Brasil, consumado em 31 de agosto de 2016.

\section{A perenidade da revolução passiva brasileira no século XXI: o bonapartismo persistente, o circuito fechado e a impossibilidade da democracia liberal-burguesa no Brasil}

Há momentos na história nos quais o movimento histórico acelera-se e os processos de mudanças e transformações sociais se acentuam de tal forma que o tempo histórico normal assume uma atipicidade tal, no qual os dias, meses e anos, parecem não conseguir mensurar e acompanhar a celeridade das mudanças e processos em curso. Assim o homem prosaico, disposto a conduzir a vida cotidiana tal qual aparece aos seus olhos, segue encaminhando as questões de ordem prática, como se a história se movimentasse por uma lei da natureza imutável. Nesses momentos, no qual a bússola e o relógio não são capazes de mensurar o tempo, tampouco o movimento histórico, a roda da história não deve ser deixada ao seu livre movimento, deve ser conduzida, freada ou acelerada, pelos sujeitos históricos capazes de movê-la. Em meados do século XIX, como tentativa de apreender o movimento histórico e as transformações profundas em curso na Europa, Marx desenvolvera uma tese, afirmando que:

\footnotetext{
Os homens fazem a sua própria história; contudo, não a fazem de livre e espontânea vontade, pois não são eles quem escolhem as circunstâncias sob as quais ela é feita [...]. A tradição de todas as gerações passadas é como um pesadelo que comprime o cérebro dos vivos. E justamente quando parecem estar empenhados em transformar a si mesmos e as coisas, em criar algo nunca antes visto, exatamente nessas épocas de crise revolucionária, eles conjuram temerosamente a ajuda dos espíritos do passado, tomam emprestados os seus nomes, as suas palavras de ordem, o seu figurino, a fim de representar, com essa venerável roupagem tradicional e essa linguagem tomada de empréstimo, as novas cenas da história mundial. Assim, Lutero se disfarçou de apóstolo Paulo, a revolução de 1789-1814 se travestiu de República Romana ora de cesarismo romano e a revolução de 1848 não descobriu nada melhor para fazer do que parodiar, de um lado, o ano de 1789 e, de outro, a tradição revolucionária de 1793-5 (MARX, 2011, p.25-6).
}

Quando se pensa no conceito de revolução passiva, duas questões se colocam: a) tratase de um tipo particular de "revolução" que se opõem a concepção de revolução popular jacobina, caracterizada por um movimento ascendente que se movimenta de "baixo para cima" e que, portanto, rompe radicalmente com a velha ordem política e social, enquanto que na revolução passiva ocorre o inverso, constituindo-se um movimento de tipo descendente e 
impondo-se de "cima para baixo"; b) a revolução passiva implica em dois momentos, o momento da restauração enquanto manifestação sociopolítica conservadora, como forma de controlar toda e qualquer possibilidade de transformação radical e efetiva da sociedade que venha de "baixo para cima"; e, o momento da renovação, no e a partir do qual parte das reivindicações da classe trabalhadora e demais classes subalternas são concedidas "pelo alto" de forma controlada. Trata-se, portanto, de uma complexa unidade de contrários estabelecida a partir do binômio modernização-conservação, que se corporificam objetiva e subjetivamente de forma articulada. Nesse sentido, no binômio modernização-conservação o momento restauração predomina e caracteriza os processos de revolução passiva, todavia, deve-se destacar a existência de modificações efetivas e, portanto, não pode ser entendida enquanto sinônimo de contrarrevolução e ou contrarreforma. Portanto, toda revolução passiva implica na efetivação de um tipo particular de reformismo "pelo alto", no e a partir do qual se forja um conjunto de modificações moleculares que implicam na mudança progressiva da composição antiga das forças, de tal forma a transformar-se efetivamente em matriz de novas mudanças em curso.

Historicamente a revolução brasileira esteve vinculada e submetida a um tipo particular de revolução-restauração, na e a partir da qual a invocação da imagem e do conceito de revolução buscou animar artificialmente processos de modernização marcados pela conservação. Ora, a revolução-restauração forjou-se no e pelo processo de formação brasileira, na e a partir da qual os movimentos sociopolíticos forjaram-se e constituíram-se por uma via gatopardista própria. Assim, geneticamente, a restauração conjura seu contrário, a revolução, como forma de bloqueá-la objetiva e subjetivamente.

Não é do passado, mas unicamente do futuro, que a revolução social do século XIX pode colher sua poesia. Ela não pode começar a dedicar-se a si mesma antes de ter despido toda a superstição que a prende ao passado. [...] A revolução do século XIX precisa deixar que os mortos enterrem seus mortos para chegar ao seu próprio conteúdo. [...] (MARX, 2011, p.28-9).

A particularidade ontogenética brasileira vincula-se a um tipo particular de tradição, na e a partir da qual a revolução-restauração instituiu um tipo particular de movimento histórico sociopolítico no e a partir do qual [...] todo um povo, que por meio da revolução acreditava ter obtido a força motriz necessária para avançar com maior celeridade, de repente se vê arremessado de volta a uma época extinta [...] (MARX, 2011, p.27). Desde a ruptura do pacto-colonial, o binômio modernização-conservação instituiu-se e enraizou-se na cultura política brasileira, enquanto via única e exclusiva dos processos de transformação e mudança 
social no Brasil, destacando-se: a) o processo de Independência de 1822; o processo de Proclamação da República de 1889; o processo da chamada Revolução de 1930; o processo da chamada Revolução de 1964; a constituição da Nova República, com a promulgação da Constituição de 1989; e, acrescentar-se-ia o Golpe de Estado soft de 2016, de tipo parlamentar-judicial midiático.

Assim como na fecundação e no parto do Estado brasileiro encontravam-se presente a contradição essencial da formação social brasileira: de um lado, a constituição de um Estado sem uma nação pretensamente liberal; de outro, um conjunto de relações sociais de produção fundamentadas no escravagismo; o Brasil do século XXI apresenta-se sob a forma da contradição de uma democracia liberal-representativa incompleta e instável, erguida sobre as bases da subordinação permanente das classes trabalhadoras e demais classes subalternas, de tal forma a bloquear estruturalmente toda e qualquer possibilidade de representação e participação ativa de tais sujeitos sociopolíticos nos processos de tomadas de decisão do país. Assim, a democracia liberal-representativa manifesta sua incompletude e instabilidade, nos momentos em que os subalternos reivindicam participação e representação no Estado brasileiro.

Nesse sentido, pode-se dizer que as Manifestações de $2013^{2}$ representaram tentativas espontâneas e difusas das classes trabalhadoras e demais classes subalternas de reivindicarem participação efetiva nos processos decisórios do país, em um cenário marcado por contradições de ordem conjunturais, todavia, que expressavam contradições de ordem estruturais da formação social brasileira: de um lado, o Estado autocrático brasileiro investindo bilhões de reais na construção de estádios de futebol, para a realização da Copa do Mundo de $2014^{3}$, no e a partir do qual se instituiu o lema "padrão Fifa", como forma de se garantir luxuosas estruturas para o desfrute das classes dominantes mundiais, ao mesmo tempo, beneficiando as grandes empreiteiras brasileiras, no âmbito da construção civil, bem como a fração de classe hegemônica no bloco no poder, de caráter rentista-financista, tanto pela via da política monetária e fiscal, quanto pela via da especulação imobiliária direta e indireta produzida pelas obras. Essa contradição de ordem imediata acabou conduzindo diversos setores da sociedade a realização de protestos que ganhariam repercussões políticas e

${ }^{2} \mathrm{O}$ GLOBO. O Brasil foi às ruas em junho de 2013. Publicado em 16 mai. 2014. Disponível em http://acervo.oglobo.globo.com/fatos-historicos/o-brasil-foi-as-ruas-em-junho-de-2013-12500090. Acessado em 04 mar. 2018.

${ }^{3}$ TCU Contabiliza R \$ 25,r bilhões de gastos com a Copa do Mundo. Publicado em 04 dez. 2014. Disponível em https://noticias.r7.com/brasil/tcu-contabiliza-r-255-bilhoes-de-gastos-com-a-copa-do-mundo-04122014.

Acessado em 04 mar. 2018. 
expandir-se-iam rapidamente, demarcando-se um caráter heterogêneo na composição do movimento. Durante os protestos, o lema "padrão Fifa" foi reivindicado para hospitais, escolas, moradias, entre outras reivindicações, constituindo-se uma aparente agenda "anti neoliberal", mas, ao mesmo tempo, carregando consigo a insígnia conservadora do antipartidarismo e antipolíticos. Os protestos de 2013 voltaram a se repetir durante os jogos, seguidos de forte estrutura repressiva ${ }^{4}$, articulada pelos entes da federação: governos federal, estaduais e municipais. De outro lado, manifestar-se-ia uma das contradições estruturais da sociedade brasileira, a profunda desigualdade que passou a se manifestar a partir da reivindicação do direito à cidade, em um contexto de acentuação da especulação imobiliária, mediada pelo aumento progressivo não somente dos imóveis, mas e fundamentalmente do aluguel e do crescimento da população em situação de rua, na medida em que tais processos redundaram em despejos individuais e coletivos. O fenômeno social em questão produziu a dilatação e expansão da periferia, expulsando os trabalhadores para regiões mais longínquas e bloqueando o acesso de parcelas significativas da classe trabalhadora e demais classes subalternas à cidade. Assim, as Manifestações de 2013, de forma desorganizada e espontânea, marcada por uma composição heterogênea, reverberou uma das contradições fundamentais do país, aparentemente contornada pela política de conciliação dos governos petistas, principalmente pela política creditícia e pelo "Programa Minha Casa, Minha Vida”, que em larga medida beneficiou muito mais aos Bancos e as grandes construtoras, do que propriamente a classe trabalhadora e demais classes subalternas. Nesse sentido, pode-se dizer que o Movimento Passe Livre ${ }^{5}$ caracterizou-se por ser o estopim de um processo de aprofundamento e agudização das contradições político-econômicas e socioculturais brasileiras, na medida em que de forma imediata, a partir das manifestações contra o aumento da tarifa de ônibus, pautava-se questões de ordem conjunturais importantes, todavia, marcadas por questões estruturais essenciais para o entendimento do processo de formação social

\footnotetext{
${ }^{4}$ G1. Protestos contra a abertura da Copa deixam feridos e detidos em SP. Publicado em 12 junh. 2014. Disponível em http://g1.globo.com/sao-paulo/noticia/2014/06/protestos-contra-abertura-da-copa-deixam-feridose-detidos-em-sp.html. Acesso em 04 marc. 2018.

${ }^{5}$ G1 Entenda os protestos em SP, contra o aumento das tarifas dos transportes. Publicado em 11 jun. 2013. Disponível em http://g1.globo.com/sao-paulo/noticia/2013/06/entenda-os-protestos-em-sp-contra-aumento-dastarifas-do-transporte.html. Acessado em 09 mar. 2018.
} 
brasileira e o conjunto de suas relações sociais contemporâneas. Deve-se destacar, ainda, o progressivo aumento de greves espalhadas pelo país, a partir de $2011^{6}$.

Sem sombra de dúvidas os tempos que sopravam das Manifestações de 2013 clamavam por mudanças. Todavia, as múltiplas determinações do processo de formação social brasileira, em um contexto de imperiosidade das mudanças, necessariamente, impôs a realidade objetiva o binômio conservação-mudança, no e a partir do qual o aspecto mudança escaparia inteiramente a capacidade de previsão dos sujeitos sociopolíticos envolvidos, na medida em que seu irmão siamês, o aspecto conservação, colocar-se-ia enquanto processo predominante. Se por um lado, a Nova República (1989-2016) abriu um novo processo de modernização-conservação, marcado por um conjunto de concessões as classes trabalhadoras e demais classes subalternas; por outro, o binômio conservação-mudança promoveu processos de transformismos profundos no âmbito da sociedade civil do mundo do trabalho, instituindo instrumentos e mecanismos de cooptação das lideranças das principais experiências de organizações autônomas da classe trabalhadora do período, particularmente pode-se citar ao menos dois: a) a criação e consolidação do Partido dos Trabalhadores, rapidamente absorvido pelo profissionalismo e pela burocratização, típicos de partidos da ordem; e, b) a criação e consolidação da Central Única dos Trabalhadores, marcada pela predominância do novo sindicalismo e pela hegemonia da política de conciliação petista. Assim, a passagem da ditadura civil-militar (1964-1985) para a democratização deu-se "pelo alto" e pela predominância da pequena política, sendo que a partir da prática do transformismo bloqueou-se qualquer possibilidade de uma revolução democrático popular no Brasil.

O Golpe de Estado soft de 2016, de tipo parlamentar-judicial-midiático, demarcou o aprofundamento e a necessidade da completude do processo de modernização-conservação aberto com a Nova República, na medida em que fechou, por um lado, um ciclo de acumulação do capital e, por outro, um modelo de representação político-eleitoral no Brasil. O esgotamento tanto do primeiro, quanto do segundo, levaram a necessidade imperiosa das frações de classes dominantes hegemônicas, que compõem o bloco no poder, a desferirem o Golpe de Estado e romper o contrato social estabelecido pela Constituição de 1988, como forma de reverter "pelo alto" as concessões feitas as classes trabalhadoras e demais classes subalternas. Como o programa de contrarreformas imposto pelo capital, não passaria pelo

\footnotetext{
${ }^{6}$ DIAS, Guilherme Soares. Número de greves em 2011 foi o maior desde 1997, diz DIEESE. Publicado em 29 nov. 2012. Disponível em http://www.valor.com.br/brasil/2922634/numero-de-greves-em-2011-foi-o-maiordesde-1997-diz-dieese. Acessado em 04 mar. 2018.
} 
crivo das urnas, bem como o Partido dos Trabalhadores teria imensas dificuldades para aprová-lo, devido sua origem e compromisso com frações importantes das classes trabalhadoras e demais classes subalternas, o Golpe de Estado se impôs pela elevação ao poder de um político paulista decadente que surgiu no mundo da política pela via do apoio ao jogo do bicho ${ }^{7}$ em São Paulo.

No âmbito do cenário de Estado de Exceção, nenhum governo eleito na e pela Nova República pôde contar com a maioria que o Governo Golpista (PMDB/PSDB) capitaneado por Michel Temer contou, de tal forma a instituir-se uma Constituinte indireta, como forma de criar uma legislação excepcional e, ao mesmo tempo, alterar a legislação "pelo alto", adequando-a tanto ao cenário de luta de classes aberta que se forjou, quanto ao novo padrão de acumulação do capital, aberto com a crise estrutural do capital. Uma das contradições fundamentais do Estado de Exceção aberto com o Governo Temer encontra-se no fato de um governo com baixíssima popularidade, chegando a $3 \%{ }^{8}$, contar com a maioria do Congresso Nacional, a ponto da Câmara dos Deputados blindar e livrar Michel Temer, por duas vezes, de denúncias da Procuradoria Geral da República, pelos crimes de corrupção passiva, organização criminosa e obstrução da justiça e que, portanto, poderiam levá-lo ao impeachment. Deve-se destacar que ambos os processos, no âmbito da Comissão de Constituição e Justiça, foram relatados por Deputados do PSDB: a) no dia 03 de agosto de 2017, por 263 a 227, a Câmara aprovou o Relatório realizado pelo Deputado Paulo Abi-Ackel $\left(\right.$ PSDB-MG) ${ }^{9}$, rejeitando a denúncia de corrupção passiva; e, b) no dia 25 de outubro de 2017 , por 251 a 233, a Câmara aprovou o Relatório realizado pelo Deputado Bonifácio de Andrada $(\text { PSDB-MG })^{10}$, rejeitando a denúncia de organização criminosa e obstrução da justiça.

Como forma de legitimar o golpe, o Judiciário movimentou-se ativamente no sentido de garantir a mudança da legislação “pelo alto”, conferindo plenos poderes a seus agentes,

\footnotetext{
7 ÉPOCA. Documento do SNI apontou relação de Temer com o jogo do bicho. Publicado em 13 mai. 2016. Disponível em https://epoca.globo.com/tempo/noticia/2016/05/documento-do-sni-apontou-relacao-de-temercom-o-jogo-do-bicho.html. Acessado em 09 mar. 2018.
}

8 FOLHA DE SÃO PAULO. Publicado em 19 dez. 2017. Disponível em http://www1.folha.uol.com.br/poder/2017/12/1944795-aprovacao-ao-governo-temer-oscila-de-3-para-6-indicaibope.shtml. Acessado em 09 mar. 2018.

${ }^{9}$ CARAM, Bernardo; MODZELESKI, Alessandra; GARCIA, Gustavo; CALGARO, Fernanda. Publicado em 02 ago. 2017. Disponível em https://g1.globo.com/politica/noticia/votacao-denuncia-temer-camara.ghtml. Acessado em 09 mar. 2018.

${ }^{10}$ CALGARO, Fernanda; MODZELESKI, Alessandra; CARAM, Bernardo. Por 251 votos a 233, Câmara rejeita enviar ao STF segunda denúncia contra Temer. Publicado em 25 out. 2017. Disponível em https://g1.globo.com/politica/noticia/segunda-denuncia-contra-temer.ghtml. Acessado em 09 mar. 2018. 
como forma de se legitimar uma legislação excepcional no processo de transição; ao mesmo tempo, o Governo Golpista (PMDB/PSDB) capitaneado por Michel Temer, em parceria com as corporações que monopolizam os meios de comunicação no Brasil, criaram o mito de que a equipe econômica do golpe era a mais eficiente da história, de tal forma a gabaritar o homem do mercado financeiro-rentista, Henrique Meireles, a colocar-se como pré-candidato as eleições presidenciais de 2018. O Golpe apareceu aos olhos do homem comum, por um lado, enquanto uma disputa política entre partidos políticos corrompidos pelo poder; por outro, enquanto possibilidade de mudança efetiva, visto que o Partido dos Trabalhadores, devido a mais de uma década de transformismo ativo, bem como de deseducação e de desmobilização das classes trabalhadoras e demais classes subalternas, não conseguia apontar saídas minimamente razoáveis que contassem com o apoio popular, para a saída da crise. A questão é que no Brasil, devido suas questões estruturais, a mudança sempre anda umbilicalmente ligada a conservação. $O$ processo de mudança se imporia, todavia, pela predominância do elemento conservação. O transformismo ativo lulopetista se traduziu em uma fuga para frente, encontrando-se presente em duas de suas ideologias mais sofisticadas: de um lado, o chamado neodesenvolvimentismo, enquanto expressão ativa de uma política neoliberal moderada; e, de outro, o lulismo, enquanto força carismática-mítica de conciliação de classes. Tanto o primeiro quanto o segundo, tratavam-se de uma conjuração do passado, a partir das quais se clamava pelo esgotado modelo desenvolvimentista instituído pela revolução passiva aprofundada pelos governos de Getúlio Vargas, a partir do qual se buscava forjar um programa que deveria conduzir o país a um novo modelo de capitalismo de Estado, fundamentado em uma pretensa coalizão nacional-popular, no e a partir do qual todos ganhariam; ao mesmo tempo, a mesma conjuração do passado reencarnava no mesmo processo, tanto o modelo, quanto a figura mítica varguista, pela via do lulismo. Tratava-se de difundir a crença de que no âmbito do binômio arcaico-moderno, o aspecto arcaico poderia ser superado a partir de avanços moleculares advindos da constituição e dilatação do aspecto moderno. Ora, nesse sentido o outro binômio conservação-mudança, acabaria por aparecer na ideologia de conciliação lulopetista de tal forma que a mudança social superaria o elemento conservação pela via da vontade política advinda do lulismo, bem como de seu programa neodesenvolvimentista. A Carta ao Povo Brasileiro ${ }^{11}$ de Lula demarca uma etapa de avanço do processo de modernização-conservação aberto com a Nova República, no e a partir do

\footnotetext{
${ }^{11}$ FOLHA DE SÃO PAULO. Leia íntegra da Carta de Lula para acalmar o mercado financeiro. Publicado em 24 jun. 2002. Disponível em http://www1.folha.uol.com.br/folha/brasil/ult96u33908.shtml. Acesso em 11 mar. 2018.
} 
qual a modernização-conservação não pode ser identificada somente como uma defesa das frações de classes dominantes, mas de frações importantes das próprias organizações autônomas das classes trabalhadoras e demais classes subalternas, na medida em que se constitui um tipo particular de transformismo ativo. $\mathrm{O}$ mito do desenvolvimento do capitalismo nacional, fora conjurando, encarnando-se na figura do neodesenvolvimentismo e do lulismo, a partir dos quais o Partido dos Trabalhadores, bem como a Central Única dos Trabalhadores abriam mão do protagonismo exercido nos anos de 1980 e início dos anos de 1990, em nome de uma governança pragmático-utilitarista. Objetivamente, o PT, bem como seu braço sindical, a CUT, abriam mão de ser um organizador social e transfeririam essa função para o Estado, absorvendo e cooptando tanto os movimentos sociais quanto o sindicatos.

Assim como a revolução passiva brasileira de longo prazo, iniciada em 1928 e concluída em 1978, demarcando-se a completude do capitalismo brasileiro, necessitou de um Golpe de Estado clássico e militarizado para consolidar-se e conduzir os processos de revolução-restauração a sua completude, no qual, a partir de 1964, predominou o elemento restauração; o processo de modernização-conservação aberto com a Nova República necessitou de um Golpe de Estado soft, para concluir os processos de modernizaçãoconservação abertos pela transição da ditadura civil-militar brasileira para a democratização do país, no e a partir do qual predominou a americanização "pelo alto”. A transição pactuada "pelo alto" abriu uma nova agenda e um novo processo de modernização-conservação no Brasil, na medida em que se constituiu um novo bloco no poder, dominado e dirigido pela fração de classes financista-rentista, afastando-se progressivamente do controle do Estado qualquer vestígio de desenvolvimentismo. Tratava-se de redesenhar o Estado "pelo alto", progressivamente, como forma de reverter às necessárias concessões feitas as classes trabalhadoras e demais classes subalternas, no processo da Constituinte; e, ao mesmo tempo, readequar o Estado a nova dinâmica do capitalismo mundial. Os Governos de Fernando Henrique Cardoso (1995-2002) foram melhores sucedidos, nesse processo, constituindo-se uma legislação autocrática "pelo alto”, via dispositivo de Emendas Constitucionais, redesenhando os fundamentos do Estado brasileiro, inclusive, bloqueando a adoção de qualquer tipo de política econômica desenvolvimentista, pela via da aprovação da Lei de Responsabilidade Fiscal ${ }^{12}$. A Nova República demarca a completude e o esgotamento da revolução passiva advinda do contrato social varguista e a necessidade de abertura de uma

${ }^{12}$ PRESIDÊNCIA DA REPÚBLICA. Lei Complementar $\mathrm{n}^{\circ}$ 101, de 04 de maio de 2000. Disponível em http://www.planalto.gov.br/ccivil_03/Leis/LCP/Lcp101.htm. Acessado em 09 mar. 2018. 
nova agenda de modernização-conservação para o Brasil, restando desse processo apenas a legislação social. Com a Nova República o binômio conservação-mudança coloca-se em outro patamar, na medida em que o capital-imperialismo impõe "pelo alto" um processo agudo de modernização, ao qual os países de capitalismo dependente e associados deveriam se subordinar.

A revolução passiva instituída pelo contrato social varguista necessitou conceder direitos sociais de diversas ordens, como forma de controlar toda e qualquer forma de organização autônoma das classes trabalhadoras e demais classes subalternas, interditando seus direitos políticos e controlando seus direitos sociais "pelo alto", pela via da criminalização de suas organizações e ao mesmo tempo pela constituição de um tipo de Sindicalismo de Estado, capaz de cooptar e controlar o movimento dos trabalhadores por dentro. Em um processo de continuidades descontínuas, o processo de modernizaçãoconservação aberto com a Nova República, necessitou conceder direitos políticos as classes trabalhadoras e demais classes subalternas, todavia, o processo de concessão colidiria frontalmente com o Estado autocrático brasileiro, bem como com o novo padrão de acumulação do capital, levando ao colapso do sistema político-eleitoral liberal-representativo e, impondo a necessidade de alterá-lo “pelo alto”, via cláusulas de barreira e via legislação extraordinária advindo do Estado de Exceção.

\section{As quatro teses de sustentação do Golpe de Estado no Brasil.}

Como tentativa de apreensão do movimento sócio histórico brasileiro, trabalhar-se-á com quatro teses estruturantes. O Golpe de Estado de 2016 demarcou a aceleração do movimento histórico no Brasil, de tal forma: a) a encerrar um ciclo histórico de estrutura e concepção de arranjo político institucional, levando ao colapso o modelo político liberalrepresentativo; b) a abrir um novo ciclo de acumulação do capital que necessariamente implica em um processo de luta de classes aberta, e, portanto, na constituição de um arranjo político-institucional representativo fechado; c) a constituir um novo redesenho do Estado autocrático brasileiro "pelo alto", devido às necessidades do novo ciclo de acumulação do capital; e, d) a reorganização do bloco no poder, na medida em que o modelo de arranjo político-institucional representativo necessariamente exigirá um fechamento progressivo do regime, que ora se faz sob a forma do Estado de Exceção, todavia, necessitará no curto prazo, criar um arranjo político institucional que lhe confira legitimidade e que do ponto de vista formal encontra-se na tentativa de imposição "pelo alto" do parlamentarismo ou semi- 
presidencialismo. Entretanto, essa mudança “pelo alto”, necessita de um consenso mínimo em torno da constituição de uma divisão dos poderes no âmbito do "novo" bloco no poder, ora travado pela luta intestina intra burguesa.

Nesse sentido, pode-se dizer que o processo em questão abriu uma crise de hegemonia no interior das classes dominantes, na medida em que o Golpe de Estado vem se aprofundando e as classes dominantes não conseguiram se unificar em torno de uma saída institucional democrática. Trata-se de um redesenho do bloco no poder, marcado por uma crise de hegemonia que se aprofunda, na medida em que o Golpe de Estado se aprofunda. Ora, trata-se de um processo marcado pela incapacidade das frações de classes dominantes governar. Deve-se levar em conta que a incapacidade de dominação e direção das classes dominantes advém do processo ontogenético brasileiro, na medida em que o tipo particular de capitalismo hipertardio corporificou-se na forma da subordinação, dependência e associação das classes dominantes brasileiras ao capital-imperialismo, de tal forma que a política de conciliação de classes colocou-se enquanto saída necessária para se garantir uma frágil governabilidade. O fictício segundo Governo Dilma (2015 - abril de 2016) foi clara representação da fissura profunda que se abriu no bloco no poder, bem como da crise de hegemonia que se desdobrou daquele processo. Mesmo diante da capacidade das frações de classes dominantes pautarem o governo, após uma derrota eleitoral de seu candidato predileto, optou-se pela via do Golpe de Estado e, necessariamente, de forma colateral, pela abertura da luta intestina intra burguesa. Apesar de não estarmos diante de uma quadratura histórica na qual as classes trabalhadoras e demais classes subalternas teriam as condições objetivas e subjetivas para se tornar classe dominante e dirigente, na medida em que a crise de hegemonia se aprofunda, o cenário pode abrir novas perspectivas.

A tentativa de se construir algum tipo de entendimento acerca do Golpe de Estado ocorrido no Brasil pós-eleições presidenciais de 2014, necessariamente implica no processo de estabelecimento de múltiplas relações complexas constituídas entre um conjunto de variáveis externas e internas, na medida em que a estrutura de dominação forjada na e pela particularidade sócio histórico brasileira fundamenta-se e articula-se a partir de um tipo de dominação integrada a uma formação social desigual, subordinada, dependente e associada à estrutura do capital-imperialismo. Nesse sentido, a dominação interna e externa se conjugam, se articulam, se retroalimentam, se amalgamam e se interseccionam no processo de formação social brasileira, instituindo-se uma relação de associação e dependência entre as classes dominantes locais e as classes dominantes do capital-imperialismo. 
Devido à genética da formação social brasileira, o Golpe de Estado ocorrido no Brasil em 2016 só pode ser compreendido à medida que se busque o entendimento do bloco no poder que se constituiu no Brasil a partir da Nova República (1989-2016), marcado pela predominância do setor rentista-financista, como forma de demarcação do colapso do nacional-desenvolvimentismo e, portanto, o aprofundamento da subordinação e dependência do Brasil no cenário geopolítico mundial, de tal forma a instituir-se um novo redesenho da associação entre as classes dominantes internas e o capital-imperialismo. Por um lado, devese buscar a exata compreensão do que significaram os processos geopolíticos de intensificação da mundialização do capital, entendido enquanto ideologia da globalização, como forma de se defender a própria desaparição dos Estados nacionais, em um cenário de fortalecimento dos Estados nacionais, ao menos, verificável no epicentro do capitalismo mundial. No Brasil, esse processo ocorrera de maneira tardia, devido às particularidades sócio históricas brasileiras. Enquanto que nos países de capitalismo central esse processo se intensificou no início dos anos de 1980, principalmente com as vitórias de Margareth Thatcher (1925-2013) em 1979, no Reino Unido; e, Ronald Reagan (1911-2004) em 1980, nos Estados Unidos; no Brasil, esse processo se intensificou nos anos de 1990. Tratava-se de um momento histórico de abertura do longevo e degenerescente regime civil-militar (19641985) que entrara em colapso, devido à nova conjuntura geopolítica, ao mesmo tempo, devido seu esgotamento político-econômico, e a ascensão de um vigoroso movimento operário e popular interno de contestação.

A nova geopolítica nascida dos anos de 1970 criou um conjunto de bancos de ideias nacionais e internacionais, como forma de se forjar certo convencimento, acerca da ideologia de dominação que mediaria o novo padrão de acumulação do capital. Os tempos eram de neoliberalismo flexível, de reestruturação produtiva e de redesenho da dominação geopolítica mundial. O que exigia necessariamente um redesenho "pelo alto" da estrutura jurídicopolítica dos Estados dependentes, subordinados e associados ao capital-imperialismo. O neoliberalismo flexível fortaleceu em escala mundial as frações rentistas e financistas, de tal forma a cimentar estruturas de blocos de poder nos Estados nacionais, fundamentadas na fração de classes rentistas e financistas, relegando as demais frações de classes de dominação um papel de associados menores do novo padrão de acumulação do capital. Esse processo significou a falência da social-democracia, na medida em que se tornou incapaz de dar respostas reformistas a um cenário de destruição e/ou anulação da autonomia das economias nacionais, da estrutura sindical e dos partidos políticos de esquerda. 
Os governos de Luís Inácio "Lula" da Silva (2003-2010) ocorreram em um processo de hegemonia do neoliberalismo flexível, consolidado por Fernando Henrique Cardoso (19952002), no Brasil. Todavia, o modelo de submissão irrestrita e incondicional ao capital rentistafinancista, adotado por FHC havia levado o país à bancarrota por três vezes ${ }^{13}$, gerando uma crise no interior do bloco no poder. A incapacidade do principal partido das classes dominantes - o Partido da Social Democracia Brasileira (PSDB) - em apontar uma saída para a crise o levou a dar um Golpe de Estado soft ${ }^{14}$, pela via da institucionalidade, a partir do qual se instituiu a reeleição ${ }^{15}$ faltando pouco mais de um ano para que ocorresse o pleito eleitoral, como forma de manter FHC no poder e consolidar o neoliberalismo flexível, no âmbito das instituições políticas brasileiras. Tratava-se de um claro processo de legislação em causa própria, a partir da qual se alterava a legislação político-eleitoral no Brasil como forma de se beneficiar aqueles que estavam no poder, ou seja, tratava-se de alterar a "regra do jogo" no meio do jogo. À época, Antônio Carlos Magalhães (PFL-BA) presidia o Senado e Michel Temer (PMDB-SP) presidia a Câmara dos Deputados, ambos, a partir de compra de votos de parlamentares de ambas casas, bem como pelo cultivo do clientelismo e do fisiologismo $^{16}$, conduziram a aprovação acelerada da Emenda Constitucional n ${ }^{\circ} 16^{17}$ que instituía a reeleição. Tratava-se de um redesenho "pelo alto" do Estado autocrático brasileiro, recém definido pela Constituição de 1988, como forma de interditar e/ou restringir qualquer possibilidade de participação e representação das classes trabalhadoras e demais classes subalternas no âmbito das instituições políticas brasileiras. Ora, a garantia da segurança jurídica e dos princípios democráticos nunca foram um valor cultivado pelas classes dominantes brasileiras, visto que a medida em que viam seu exclusivismo político ameaçado, recorriam a Golpes de Estado, soft ou hard, como forma de recomposição do Estado autocrático brasileiro.

\footnotetext{
${ }^{13}$ FOLHA DE SÃO PAULO. Ciro afirma que governo FHC "quebrou" o Brasil três vezes. Publicado em 30 nov. 2004. Disponível em http://politica.estadao.com.br/noticias/geral,ciro-afirma-que-governo-fhc-quebrou-o-brasiltres-vezes,20041130p33184. Acessado em 07 jan. 2018.
}

${ }^{14}$ MACHADO, Ivan Carlos Novaes. Publicado em nov. 1997. Disponível em: https://jus.com.br/artigos/1509/inconstitucionalidade-da-emenda-da-reeleicao. Acessado em 07 jan. 2018.

${ }^{15}$ JORNAL BRASIL 247. Publicado em 28 mai. 2015. Disponível em: https://www.brasil247.com/pt/247/poder/182792/Reelei\%C3\%A7\%C3\%A3o-que-custou-mais-caro-aoPa\%C3\%ADs-foi-a-de-FHC.htm. Acessado em 07 jan. 2018.

${ }^{16}$ JORNAL GGN. Publicado em 20 out. 2014. Disponível em: https://jornalggn.com.br/noticia/provas-dacompra-votos-pela-reeleicao-de-fhc-eram-cabais-conta-jornalista. Acessado em 07 jan. 2018.

${ }^{17}$ PRESIDÊNCIA DA REPÚBLICA. Emenda Constitucional $\mathrm{n}^{\circ} 16$, de 04 de junho de 1997. Disponível em http://www.planalto.gov.br/ccivil_03/constituicao/emendas/emc/emc16.htm. Acessado em 13 jan. 2018. 
Fundamentando-se nas questões estruturais expostas, bem como no redesenho geopolítico internacional ocorrido a partir dos anos de 1970 e das mudanças internas do bloco no poder no Brasil, trabalhar-se-á com a tese de que a partir da Constituição de 1988 abriu-se no Brasil um novo processo de modernização-conservação, na medida em que a Constituição de 1988 reafirmou um dos elementos importantes do contrato social varguista, de tal forma a manter e estender, em alguns aspectos, certa legislação social, como forma de cimentar a estrutura de dominação de classes no Brasil, claramente marcada pela política de conciliação de classes, ao mesmo tempo, abriu-se um novo ciclo de acumulação do capital que necessitava destruir a legislação social precária instituída, como forma de se desenvolver, fortalecer e institucionalizar o novo bloco no poder. Portanto, a Nova República nasceu a partir de uma contradição insuperável, que acabou por determinar a forma e o conteúdo dos partidos políticos da ordem, por um lado, construir coalisões a partir das quais o pacto de governança passaria pela garantia e regulação da legislação social; por outro, criar as condições jurídico-políticas para o novo ciclo de acumulação do capital, fundamentado no neoliberalismo flexível. Devido a essa contradição fundamental, a política de conciliação se colocaria enquanto único instrumento político capaz de cimentar o presidencialismo de coalizão brasileiro.

Com o influxo dos movimentos sociais e populares advindos do final dos anos de 1970 e início dos anos de 1980, as classes dominantes foram obrigadas a fazer concessões de diversas ordens as classes trabalhadoras e demais classes subalternas, naquilo que diz respeito à garantia de direitos civis, políticos e sociais. Todavia, apesar de ter sido obrigada a fazer um conjunto de concessões, no processo de realização da Constituinte de 1988, buscou controlar efetivamente a transição da ditadura civil-militar (1964-1985), a partir da derrota da Emenda Constitucional Dante de Oliveira ${ }^{18}$, bem como mantendo um conjunto de instrumentos políticos de repressão e produção de consenso, próprios da ditadura civil-militar, dos quais se poderia citar fundamentalmente dois: a) no primeiro caso, a manutenção da Polícia Militar ${ }^{19}$; e, b) no segundo caso, a manutenção do monopólio ${ }^{20}$ dos meios de

18 CÂMARA DOS DEPUTADOS. Publicado em 22 abr. 2014. Disponível em: http://www2.camara.leg.br/camaranoticias/radio/materias/REPORTAGEM-ESPECIAL/466301-DIREITAS-JAREJEICAO-DA-EMENDA-DANTE-DE-OLIVEIRA-MARCA-A-HISTORIA-DO-PAIS-BLOCO-1.html Acessado em 07 jan. 2018.

${ }^{19}$ NEME, Cristina. A instituição policial na ordem democrática: o caso da Polícia Militar do Estado de São Paulo. Publicado em: dez. 1999. Disponível em: http://www.nevusp.org/downloads/down147.pdf Acessado em 07 jan. 2018. 
comunicação $^{21}$. Ambos extremamente úteis ao cenário de restauração que se seguiria pósConstituinte de 1988.

Deve-se destacar que a Nova República, enquanto representação farsesca de um regime democrático foi forjada a partir de dois partidos políticos da modernização conservadora: o $\mathrm{PSDB}^{22}$, enquanto principal partido das classes dominantes forjou uma espécie de centro de forças atrativo de partidos de centro-direita e com estrutura programática similar a sua, como forma de desenhar um presidencialismo de coalizão de centro-direita, como se pode verificar na base de sustentação dos governos de FHC (PSDB-PFL); e, o PT ${ }^{23}$, enquanto principal partido das classes trabalhadoras forjou um conjunto de organizações políticas, a partir das quais atraiu para seu campo de influência os principais partidos de centro-esquerda e os principais movimentos sociais e sindicais do país, sendo a criação da Central Única dos Trabalhadores (CUT) seu principal instrumento de controle e cooptação das lideranças das classes trabalhadoras e demais classes subalternas. Portanto, pode-se observar dois tipos de movimento na constituição da Nova República, um de tipo descendente e outro de tipo ascendente, sendo que ambos se encontram na e pela política de conciliação de classes. Nesse tabuleiro, o tradicional PMDB apareceria como uma espécie de peão, fundamental para cimentar o presidencialismo de coalizão brasileiro, na medida em que sua política centrista poderia se encaixar tanto em uma perspectiva de centro-esquerda, quanto de centro-direita, a depender da correlação de forças e dos interesses locais e regionais de suas principais lideranças políticas. Apesar de caracterizarem-se por serem partidos com origens socioculturais e político-econômicas distintas: o PSDB, advindo de uma perspectiva cupulista, nascido de uma cisão interna do PMDB dentro do parlamento e da institucionalidade enquanto representação objetiva e subjetiva das classes dominantes; e, o PT nascido das tentativas de constituição de organizações autônomas das classes trabalhadoras e demais classes subalternas; o ponto de intersecção que os relacionam de forma umbilical encontra-se

\footnotetext{
${ }^{20}$ EBC TV BRASIL. Jurista defende que o monopólio dos meios de comunicação é uma ameaça a democracia. Publicado em 03 fev. 2015. Disponivel em: http://tvbrasil.ebc.com.br/vertv/post/jurista-defende-que-omonopolio-sobre-os-meios-de-comunicacao-e-uma-ameaca-a-democracia Acessado em 07 jan. 2018.

${ }^{21}$ FERNANDES, André de Godoy. Meios de comunicação social no Brasil: promoção do pluralismo, direito concorrencial e regulação. Publicado em jan. 2009. Disponível em http://www.nevusp.org/downloads/down147.pdf. Acessado em 07 jan. 2018.

${ }^{22}$ ROMA, Celso. A institucionalização do PSDB entre 1988 e 1999. Publicado em jun. 2002. Disponível em: http://www.redalyc.org/html/107/10704906/. Acessado em 07 jan. 2018.
}

${ }^{23}$ SILVA, Marcelo Lira. O projeto de governança do Partido dos Trabalhadores e sua identidade com o projeto de modernização conservadora (2003-2015). Publicado em 24 ago. 2015. Disponível em: http://www.niepmarx.blog.br/MM2015/anais2015/mc68/Tc684.pdf. Acessado em 07 jan. 2018. 
na adoção de uma política de conciliação de classes, como forma de pactuar os fundamentos da Nova República. O que os unificavam era a política de conciliação de classes centrista, mediada pela defesa da institucionalidade política enquanto único e exclusivo instrumento político de governança. Portanto, a necessidade de estruturação de um presidencialismo de coalizão ${ }^{24}$ que necessariamente dependia da atração de partidos do centro, principalmente o PMDB, para a efetivação da governabilidade passou a ser um dos principais problemas para os partidos da ordem que chegavam ao Planalto Central. Tratar-se-ia da afirmação pura da realpolitik, enquanto mecanismo e instrumento político, a partir do qual se viabilizaria a governabilidade, independentemente da concepção e do projeto de governo.

A política adotada pelo PT era completamente distinta e avessa àquela adotada pelos Partidos Comunistas, na medida em que estes se fundamentavam em uma perspectiva de constituição de uma dualidade de poderes, como forma de se construir o Estado Socialista. Diferentemente, o PT distanciava-se da constituição da dualidade de poderes ${ }^{25}$, por um lado, afastando o partido dos movimentos sindical, social e popular, de tal forma a instituir processos profundos de profissionalização e burocratização do partido e do movimento sindical sob sua influência, criando uma cisão profunda entre direção e massa; e, por outro, cooptando as lideranças de tais movimentos, como forma de desmobilizar e deseducar os movimentos, atraindo-os para dentro da estrutura estatal, como forma de constituir um tipo de governança fundamentado nos interesses das classes dominantes, apoiado e gerido pelas lideranças das classes trabalhadoras e demais classes subalternas. Ora, tratara-se de um tipo de transformismo ativo.

Luís Inácio "Lula" da Silva chegou à Presidência da República a partir de tais processos. Por um lado, Lula manteve a política econômica de FHC, fundamentada no tripé macroeconômico neoliberal ortodoxo-recessivo e indicando para o Banco Central o homem de confiança do capital rentista-financista mundial, Henrique Meirelles ${ }^{26}$; por outro, para combater a crise, adotou tímidas medidas anticíclicas, como a política de valorização do

\footnotetext{
${ }^{24}$ OLIVEIRA, Eduardo de Figueiredo Santos Barbarela e. Presidencialismo de coalizão: o jeito brasileiro de governar. Revista Habitus: Revista da Graduação em Ciências Sociais do IFCS/UFRJ, Rio de Janeiro, v. 12, n. 2, p. 70-79, dezembro. 2014. Semestral. Disponível em: https://revistas.ufrj.br/index.php/habitus/article/viewFile/11438/8388. Acesso em: 07 jan. 2018.

${ }^{25}$ GARCIA, Janaina. Frei Betto: "inquilino no governo, PT tomou chega para lado dona da casa". Publicado em 19 nov. 2016. Disponível em https://noticias.uol.com.br/politica/ultimas-noticias/2016/11/19/frei-betto-pt-temque-descer-do-salto-e-calcar-sandalias-da-humildade.htm. Acessado em 07 jan. 2018.

${ }^{26}$ BONFANTI, Cristiane; SIMÃO, Edna. Meirelles diz que política econômica de Lula foi positiva para o país. Publicado em 10 mar. 2017. Disponivel em: http://www.valor.com.br/politica/4895170/meirelles-diz-quepolitica-economica-de-lula-foi-positiva-para-o-pais. Acessado em 07 jan. 2018.
} 
salário mínimo ${ }^{27}$ e a adoção de políticas sociais focalizadas, tendo como carro-chefe o Programa Bolsa Família ${ }^{28}$, bem como um conjunto de medidas creditícias, como forma de estimular a economia interna, expandindo o mercado de consumo ${ }^{29}$, via endividamento progressivo das famílias. Tratava-se, portanto, de um tipo de inclusão de pés de barro, ao mesmo tempo, controlada ${ }^{30}$ e pela via do consumo, caracterizada essencialmente pela despolitização e desorganização das classes trabalhadoras e demais classes subalternas.

[...] Ao se deixarem conduzir pelos democratas frente a um acontecimento como esse e ao esquecerem o seu interesse revolucionário por força de uma sensação momentânea de bem-estar, eles renunciaram à honra de ser um poder conquistador, submeteram-se à sua sina, comprovaram que a derrota de junho de 1848 os havia incapacitado para a luta por muitos anos e que o processo histórico, num primeiro momento, necessariamente voltaria a desenrolar-se por cima de suas cabeças. [...] (MARX, 2011, p.85-6).

Deve-se destacar que o Judiciário, a partir de suas diversas Cortes, bem como os órgãos de controle do Estado, tais como Ministérios Públicos ${ }^{31}$ e Polícia Federal ${ }^{32}$, adquiriram poder e grande autonomia com a promulgação da Constituição de 1988, de tal forma que os governos petistas (2003-2016) aprofundaram tal autonomia em seus governos, adotando uma política de recomendação daqueles indicados pelos pares em determinadas áreas para assumirem cargos importantes na República, o que enraizou e fortaleceu um forte espírito corporativo nas instituições públicas brasileiras, principalmente no âmbito das diversas instâncias do Judiciário e nos órgãos de controle brasileiros, que na medida em que se fortaleceu passou a movimentar-se e atuar politicamente no âmbito das instituições jurídicopolíticas brasileiras. Como a política não aceita vacância de poder, os espaços de poder no

\footnotetext{
${ }^{27}$ SOUEN, Jacqueline Aslan. A política do salário mínimo no Governo Lula. Publicado em 2013. Disponívelem http://repositorio.unicamp.br/bitstream/REPOSIP/286108/1/Souen_JacquelineAslan_M.pdf. Acessado em 07 jan. 2018.

${ }^{28}$ Bolsa família 2003-2010: avanços e desafios / organizadores: Jorge Abrahão de Castro, Lúcia Modesto. Brasília: Ipea, 2010.
}

29 MORAIS, Lecio; SAAD-FILHO, Alfredo. Da economia política à política econômica: o novodesenvolvimentismo e o governo Lula. Publicado em dez. 2011. Disponível em http://www.scielo.br/scielo.php?script=sci_arttext\&pid=S0101-31572011000400001. Acessado em 07 jan. 2018.

${ }^{30}$ FOLHA DE SÃO PAULO. Entrevista Rudá Ricci: inclusão na era Lula deixa bomba-relógio para Dilma

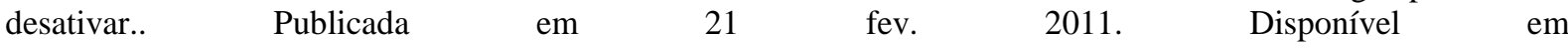
http://www1.folha.uol.com.br/fsp/poder/po2102201107.htm. Acessado em 07 jan. 2018.

31 KERCHE, Fábio. Autonomia e Discricionariedade do Ministério Público no Brasil. Publicado em 2007. Disponível em: http://www.scielo.br/pdf/dados/v50n2/a02v50n2. Acessado em 07 jan. 2018.

32 QUEIROS, Luiz de. Com PT, PF realizou 50 vezes mais operações do que com FHC. Publicado em 20 jul. 2014. Disponível em: https://jornalggn.com.br/noticia/com-pt-pf-realizou-50-vezes-mais-operacoes-do-que-comfhc. Acessado em 07 jan. 2018. 
âmbito do Judiciário e dos órgãos de controle estatais rapidamente foram ocupados politicamente, sendo utilizados para favorecer concepções e projetos políticos vinculados aos interesses das classes dominantes. Novamente, o binômio mudança-conservação passaria a atuar decisivamente, tanto com relação ao Judiciário que até a Constituição de 1988 era um mero apêndice do Executivo, quanto dos órgãos de controle, a exemplo dos Ministérios Públicos, que emergiram como uma mudança significativa a partir da Constituição de 1988, todavia, o elemento que predominou em suas estruturas internas foi o da conservação.

No âmbito da geopolítica do século XXI, abriu-se um cenário de multipolaridade e pôde-se observar o recrudescimento do imperialismo ianque, a partir da criação e difusão da ideologia do terrorismo ${ }^{33}$ islâmico, instituída pelos EUA após os ataques de 11 de setembro de 2001. Ao forjar uma política de segurança ofensiva e beligerante, os EUA criaram medidas de aproximação dos Ministérios Públicos e das Polícias Federais de diversos países à CIA ${ }^{34}$. Nesse processo, os Ministérios Públicos e a Polícia Federal tornaram-se instrumentos políticos de ação e realização dos interesses da política de segurança ianque, umbilicalmente associada a sua política externa. Portanto, os Ministérios Públicos e a Polícia Federal emergiram no século XXI enquanto novos sujeitos políticos e tornaram-se figuras centrais no processo de deflagração do Golpe de Estado ${ }^{35}$ no Brasil, no ano de 2016. Nesse processo de aproximação das instituições públicas de segurança ianques com instâncias do Judiciário e órgãos de controle, a partir do denominado "Projeto Pontes", pode-se observar um intensivo processo de treinamento de agentes judiciais brasileiros de todos os Estados da Federação, bem como de 50 policiais federais. $\mathrm{O}$ caso mais emblemático pode ser analisado a partir da emergência da principal liderança jurídico-política da Operação Lava Jato, o até então desconhecido juiz Sergio Fernando Moro (1972 - ). O Documento comprobatório do "Projeto Ponte” foi trazido a público pelo Wikileaks, e determinava o aprofundamento do treinamento nos Estados de Curitiba, São Paulo e Campo Grande: epicentro da Operação Lava Jato.

Deve-se destacar que o prelúdio ao Golpe de Estado no Brasil encontra-se na Ação Penal 470 - politicamente denominada de "Mensalão", como forma de criminalizar o Partido

\footnotetext{
${ }^{33}$ SILVA, Luiz Fernando da. A política externa estadunidense no atual quadro político sul-americano. Publicado em 17 jan. 2011. Disponível em: http://www.scielo.org.mx/scielo.php?script=sci_arttext\&pid=S166585742011000100005. Acessado em 07 jan. 2018.

${ }^{34}$ CALDEIRA, João Paulo: Wikileaks revela treinamento de Moro nos EUA. Publicado em 05 jul. 2016. Disponível em: https://jornalggn.com.br/noticia/wikileaks-revela-treinamento-de-moro-nos-eua. Acessado em 07 jan. 2018.

${ }^{35}$ REVISTA GGN. Moro, Lava Jato e interesses dos Estados Unidos. Publicado em 24 jun. 2017. Disponível em: https://jornalggn.com.br/noticia/moro-lava-jato-e-interesses-dos-eua. Acessado em 07 jan. 2018.
} 
dos Trabalhadores e suas principais lideranças políticas -, a partir do qual emergiu no Brasil um tipo específico de atuação política no âmbito do Poder Judiciário e órgãos de controle de Estado, que a partir do Ministro do Supremo Tribunal Federal, Joaquim Barbosa ${ }^{36}$, passou a instrumentalizar a teoria do domínio do fato $^{37}$, como forma de corroer princípios importantes da Constituição de 1988 e criar os fundamentos da aliança entre os meios de comunicação e o Poder Judiciário no Brasil, forjando-se um inimigo interno comum a ser combatido: a corrupção produzida e enraizada pelo Partido dos Trabalhadores. Joaquim Barbosa, bem como Sergio Moro $^{38}$, foram alçados a condição de heróis nacionais e projetados a condição de figuras políticas-pública, inclusive, ambos cogitados à presidência da República em $2014^{39}$ e em $2018^{40}$. Na ocasião, a cúpula do PT fora completamente dizimada, arranhando profundamente a imagem do partido junto à sociedade brasileira. Todavia, mesmo diante de um cenário adverso, produzido pela Ação Penal 470, tanto a ideologia de conciliação de classes corporificado no fenômeno do lulismo (chegando a 83\% de aprovação, ao final de seu mandato $)^{41}$, quanto a relativa efetividade da ideologia neodesenvolimentista, que contava com um mercado internacional favorável a economia brasileira, o governo manteve-se, reelegeu-se e conseguiu, ao menos aparentemente, se fortalecer no segundo governo Lula, a partir do enraizamento do lulismo ${ }^{42}$.

\footnotetext{
${ }^{36}$ NOGUEIRA, Claudio; GÓES, Bruno; PIMENTEL, Leonardo; ALLEMAND, Marcio; SOARES, Rafael. José Dirceu é condenado por corrupção ativa por 8 a 2. Publicado em 10 out. 2012. Disponível em: https://oglobo.globo.com/brasil/jose-dirceu-condenado-por-corrupcao-ativa-pelo-placar-de-8-2-6362347.

Acessado em 07 jan. 2018.

${ }^{37}$ BITENCOURT, Cezar Roberto. A teoria do domínio do fato e a autoria colateral. Publicado em 18 nov. 2012. Disponível em: https://www.conjur.com.br/2012-nov-18/cezar-bitencourt-teoria-dominio-fato-autoria-colateral. Acessado em 07 jan. 2018.
}

${ }^{38}$ LONDRES, Mariana. Moro teria até $67,8 \%$ dos votos para presidente, diz pesquisa. Publicada em 10 mar. 2016. Disponível em: https://noticias.r7.com/brasil/se-eleicao-fosse-hoje-juiz-sergio-moro-teria-ate-678-dosvotos-para-presidente-diz-pesquisa-10032016. Acessado em 08 jan. 2018.

${ }^{39}$ MENDONÇA, Ricardo. Joaquim Barbosa é o $2^{\circ}$ voto mais influente da eleição, diz Datafolha. Publicado em 06 jun. 2014. Disponível em http://www1.folha.uol.com.br/poder/2014/06/1465888-joaquim-barbosa-e-osegundo-voto-mais-influente-da-eleicao.shtml. Acessado em 08 jan. 2018.

${ }^{40}$ PEREIRA, Joelma. Joaquim Barbosa não descarta presidência em 2018 e vê repúdio as maiores siglas nas eleições. Publicado em 21 nov. 2017. Disponivel em: http://congressoemfoco.uol.com.br/noticias/joaquimbarbosa-nao-descarta-disputar-presidencia-em-2018-e-ve-repudio-as-maiores-siglas-nas-eleicoes/. Acessado em 08 jan. 2018.

${ }^{41}$ DATAFOLHA. Acima das expectativas, Lula encerra mandato com melhor avaliação da história. Publicado em 20 dez. 2010. Disponível em http://datafolha.folha.uol.com.br/opiniaopublica/2010/12/1211078-acima-dasexpectativas-lula-encerra-mandato-com-melhor-avaliacao-da-historia.shtml. Acessado em 08 jan. 2018.

${ }^{42}$ SINGER, André. Os sentidos do lulismo: reforma gradual e pacto conservador. - São Paulo: Companhia das Letras, 2012. 
A seletividade do Judiciário brasileiro presente na Operação Lava Jato já se encontrava presente na Ação Penal 470. Tal tese pode ser comprovada a partir da comparação e observação dos ritos e procedimentos adotados pelo Judiciário brasileiro naquilo que diz respeito à Ação Penal 470 e a Operação Lava Jato, com a Ação Penal 536 - "Mensalão tucano", pouco ou nada divulgado pelas corporações que monopolizam os meios de comunicação. Na ocasião, Eduardo Azeredo $(1948 \text { - })^{43}$ - único condenado na Ação Penal 536 -, ex-presidente nacional do PSDB, institucionalizou o procedimento de transferência de dinheiro público para o partido, quando governador de Minas Gerais em 1998. Dos 15 denunciados em 20 de novembro de 2007, 12 se tornaram réus em 2009, apenas um Eduardo Azeredo - foi condenado em $1^{\text {a }}$ instância a 20 anos e 10 meses de prisão, por peculato e lavagem de dinheiro, e recorre em liberdade o julgamento de $2^{\mathrm{a}}$ instância. Dos 12 indiciados, Fernando Soares morreu sem ser julgado e Walfrido dos Mares Guia, Cláudio Mourão e Lauro Wilson chegaram à idade de prescrição dos crimes cometidos ${ }^{44}$. Em 19 de fevereiro de 2014, Eduardo Azeredo renunciou ao mandato de deputado por Minas Gerais ${ }^{45}$ para evitar a cassação, sair dos holofotes e enterrar o caso até sua prescrição, pela via das negociações com o Judiciário brasileiro. Por outro lado, a Ação Penal 470 surgiu a partir das conclusões da CPI dos Correios, trazida a público pelo jornal Folha de São Paulo, no dia 6 de junho de 2005, a partir de uma entrevista com o Deputado Roberto Jefferson (PTB-SP) ${ }^{46}$, na qual o parlamentar denunciava a existência de pagamento de propinas a parlamentares para aprovar as medidas do governo. O esquema teria ocorrido durante os anos de 2003 e 2004 e funcionava a partir de pagamento mensal de $\mathrm{R} \$ 30$ mil, pagos pelo tesoureiro do PT, Delúbio Soares, aos congressistas que votassem as medidas do governo. Após quatro meses e meio de julgamento, a partir do personalismo político do Ministro Joaquim Barbosa e de suas ginásticas hermenêuticas jurídicas, o STF decidiu pela condenação de 25 dos 38 réus do

${ }^{43}$ COUTINHO, Mateus; GINI, Rodrigo. Azeredo é condenado a 20 anos de prisão por mensalão tucano. Publicado em: $16 \mathrm{dez}$ 2015. Disponível em: http://politica.estadao.com.br/blogs/fausto-macedo/azeredo-econdenado-a-20-anos-de-prisao-por-mensalao-tucano/. Acesso em: 19 nov 2017.

44 LADEIRA, Pedro. Citados no mensalão tucano se beneficiam de prescrições. Publicado em 30 jul. 2014. Disponível

Em

http://tools.folha.com.br/print?site=emcimadahora\&url=http://www1.folha.uol.com.br/poder/2017/06/1893632citados-no-mensalao-tucano-se-beneficiam-de-prescricoes.shtml. Acessado em 08 jan. 2018.

${ }^{45}$ G1. Réu no mensalão do PSDB mineiro, o deputado Eduardo Azeredo renuncia. Publicado em 19 fev. 2014. Disponível em http://g1.globo.com/jornal-nacional/noticia/2014/02/reu-no-mensalao-do-psdb-mineiro-deputadoeduardo-azevedo-renuncia.html. Acessado em 08 jan. 2018.

46 FOLHA DE SÃO PAULO. Jefferson denuncia mesada paga pelo tesoureiro do PT. Publicado em 06 jun. 2005. Disponível em http://www1.folha.uol.com.br/folha/brasil/ult96u69402.shtml. Acessado em 31 jan. 2018. 
processo. Na ocasião, entrou para a história do Estado autocrático brasileiro o pronunciamento da Ministra do Supremo Tribunal Federal, Rosa Weber: "Não tenho prova cabal contra Dirceu - mas vou condená-lo porque a literatura jurídica me permite" ${ }^{\$ 7}$. De acordo com os acusadores, que instrumentalizaram a teoria do domínio do fato, havia se estabelecido um esquema de corrupção que havia sido organizado pelo núcleo dirigente do Partido dos Trabalhadores e, portanto, chefiado pelo Ministro da Casa Civil do primeiro governo Lula, José Dirceu. Ao mesmo tempo, chegou-se à conclusão de que existiria um núcleo mineiro, no qual Marcos Valério aparecia como operador do mensalão. Marcos Valério foi condenado pelo STF por utilizar suas empresas de publicidade para desviar dinheiro público e repassá-lo a parlamentares. Deve-se destacar ainda que Kátia Rabello, dona do Banco Rural e diretores da instituição financeira foram denunciados por formação de quadrilha, gestão fraudulenta e lavagem de dinheiro. Desenhava-se claramente o caráter das vitórias eleitorais do período lulopetista de 2006, 2010 e 2014: vitórias de Pirro.

A Ação Penal 470 enfraqueceu o governo Lula, de tal forma a ficar suscetível ao jogo do clientelismo e do fisiologismo promovido pelo PMDB, sendo obrigado, para garantir a governabilidade, a entregar setores estratégicos do governo aos peemidebistas. Não por um acaso, no dia 30 de novembro de 2006, o Conselho Nacional do PMDB $^{48}$ aprovou a participação do partido no governo Lula. A época, Michel Temer era presidente nacional do PMDB e havia apoiado a candidatura de Geraldo Alckmin (PSDB-SP) para Presidente da República. O PT havia contado em seu primeiro mandato com o apoio e a participação restrita do PMDB de Renan Calheiros (PMDB-AL) e José Sarney (PMDB-AP). Todavia, após as eleições de 2006, com a reeleição de Lula, Michel Temer conduziu o PMDB unificado para a base do segundo Governo Lula. Pode-se dizer que a ascensão e fortalecimento político de Eduardo Cunha (PMDB-RJ) se deu nesse processo de adesão do PMDB ao governo de coalizão de Lula. Portanto, a política de conciliação petista, apesar de não ter sido responsável pela fecundação, certamente, foi a parteira que gerou o poder político de Eduardo Cunha no Congresso Nacional, a partir do qual Dilma Rousseff seria derrubada em 2016. Nesse processo, Eduardo Cunha foi eleito Presidente da Comissão de Constituição e Justiça (CCJ)

\footnotetext{
${ }^{47}$ REVISTA FORUM. Paulo Moreira Leite: condenado sem domínio nem fato. Publicado em 13 nov. 2012. Disponível em https://www.revistaforum.com.br/mariafro/2012/11/13/paulo-moreira-leite-condenado-semdominio-nem-fato/. Acessado em 09 mar. 2018.

${ }^{48}$ COLON, Leandro. PMDB aprova participação no governo de coalizão de Lula. Publicado em 30 nov. 2006. Disponível em http://g1.globo.com/Noticias/Politica/0,AA1370004-5601,00PMDB+APROVA+PARTICIPACAO+NO+GOVERNO+DE+COALIZAO+DE+LULA.html. Acesso em 25 jan. 2018.
} 
da Câmara de Deputados, de tal forma a atuar em favor da pauta conservadora da chamada bancada evangélica. O PMDB adquiriu tamanha magnitude no segundo Governo Lula, que na sucessão presidencial impôs ao PT a vice-presidência com a Chapa Dilma/Temer, apoiada por Cunha. No Governo Dilma (2011-2014), Eduardo Cunha adquiriu projeção nacional, tornando-se líder do PMDB na Câmara em 2013 e conduzindo os interesses dos 81 deputados federais do PMDB na Câmara. A desavença de Cunha com o Planalto adveio da Medida Provisória dos Portos $^{49}$, processo no qual teve diversas de suas propostas derrotadas, levandoo a alinhar-se a oposição como forma de obstruir a votação e desgastar o governo, de tal forma que a sessão durou 41 horas.

Nas eleições de 2014, o PMDB ratificou a Chapa Dilma/Temer, todavia, Eduardo Cunha - já consolidado como liderança nacional do PMDB -, apoiou implicitamente a candidatura de Aécio Neves (PSDB-MG), de tal forma a assumir o discurso de independência em relação ao Governo. No final do ano de 2014, Eduardo Cunha lançou sua candidatura à Presidência da Câmara dos Deputados, concorrendo com Arlindo Chinaglia (PT-SP), Júlio Delgado (PSB-MG) e Chico Alencar (PSOL-RJ). A candidatura de Cunha o colocou em rota de colisão com o governo, de tal forma a buscar no "baixo clero”, a partir da prática irrestrita e ilimitada do fisiologismo e do clientelismo, o apoio necessário a sua eleição. Em fevereiro de 2015, Cunha consolidava seu poder no Parlamento brasileiro, elegendo-se Presidente da Câmara e colocando-se na linha sucessória presidencial. Na votação, Eduardo Cunha ganhou em primeiro turno com 267 votos; contra, 136 votos de Chinaglia (PT-SP); 100 votos de Júlio Delgado (PSB-MG); e, 8 votos de Chico Alencar (PSOL-RJ). O processo eleitoral de sucessão para a Presidência da Câmara dos Deputados aprofundou e fortaleceu o discurso de independência frente ao Planalto, proferido por Cunha. Pode-se dizer que a eleição de Cunha à Presidência da Câmara demarcou o colapso do Governo Dilma e sua capacidade de governar.

Diferentemente dos governos Lula (2003-2010) que contou com um mercado internacional favorável, contando com altos preços dos produtos primários e das

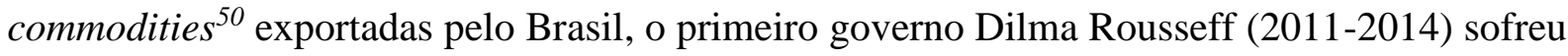
drasticamente com os impactos da crise mundial de 2008, acarretando uma forte perda de

\footnotetext{
${ }^{49}$ AMATO, Fábio; PASSARINHO, Nathalia. Entenda os principais pontos da MP dos portos aprovada pelo Congresso. Publicada em 16 mai. 2013. Disponível em http://g1.globo.com/politica/noticia/2013/05/entenda-osprincipais-pontos-da-mp-dos-portos-aprovada-pelo-congresso.html. Acesso em 10 mar. 2018.

${ }^{50}$ CASTRO, José Roberto. As commodities e seu impacto na economia brasileira. Publicado em 31 mar. 2016. Disponível em https://www.nexojornal.com.br/explicado/2016/03/31/As-commodities-e-seu-impacto-naeconomia-do-Brasil. Acessado em 07 jan. 2018.
} 
arrecadação do Estado nos anos que se seguiram. Frente a crise mundial, os instrumentos de governo adotados pelos governos Dilma tiveram pouco êxito, devido a queda de arrecadação do Estado ${ }^{51}$. Delineavam-se os primeiros elementos de fissura do bloco no poder, a partir do qual Lula havia governado. $\mathrm{O}$ aprofundamento da crise econômica produziu uma crise política que fora se aprofundando progressivamente durante o primeiro governo Dilma Rousseff $(2011-2014)^{52}$.

O olho do furacão da crise política no Brasil começou a dar sinais de força e mostrarse com a eclosão progressiva de greves em 2011, bem como com as Manifestações de $2013^{53}$, em larga medida, pautada por um forte descontentamento de setores da juventude que passaram a reivindicar um conjunto de direitos sociais, ameaçados pelos desdobramentos da crise mundial e da guinada à direita que o governo vinha apontando. As Manifestações de 2013 geraram profundo desgaste ao governo Dilma Rousseff, devido sua imaturidade e incapacidade política, bem como devido à incompetência de sua equipe de governo. $\mathrm{O}$ desgaste rapidamente foi absorvido por setores tradicionais e conservadores que passaram a instrumentalizá-lo contra o governo. Os grupos conservadores haviam assimilado o potencial de contestação advindo das Manifestações de 2013, todavia, em uma perspectiva de sinais trocados, no qual prevaleceu o aspecto conservação. $O$ descontentamento popular rapidamente foi absorvido e transformado em capital político, sendo utilizado tanto no processo de acirramento das eleições presidenciais de 2014, quanto no processo de derrubada do governo eleito, promovendo-se protestos por todo país, durante o ano de 2015, destacandose as manifestações: a) de 15 de março, que levou à Avenida Paulista 210 mil pessoas; b) de 12 de abril, que levou às ruas da Avenida Paulista 100 mil pessoas; e, c) de 16 de agosto, que levou às ruas da Avenida Paulista 135 mil pessoas (levantamento realizado pelo DATAFOLHA $^{54}$ ). A partir da constituição de um conjunto de Aparelhos Privados de

\footnotetext{
${ }^{51}$ CARVALHO, Laura. A PEC 241 pode prolongar a crise. Publicado em 13 out. 2016. Disponível em: http://tools.folha.com.br/print?site=emcimadahora\&url=http://www1.folha.uol.com.br/colunas/lauracarvalho/2016/10/1822278-pec-241-pode-prolongar-a-crise.shtml. Acessado em 07 jan. 2018.
}

${ }^{52}$ FONSECA, Francisco. As três crises do governo Dilma. Publicada em 14 jul. 2015. Disponivel em: https://www.cartamaior.com.br/?/Editoria/Politica/As-tres-crises-do-governo-Dilma/4/33990. Acessado em 07 jan. 2018.

${ }^{53}$ SAMPAIO Jr., Plínio de Arruda (Org.). Jornadas de Junho: a revolta popular em debate. - São Paulo: ICP, 2014.

${ }^{54}$ FOLHA DE SÃO PAULO. Manifestações anti-Dilma reuniu 40,3 mil pessoas mostra Datafolha. Publicado em 132 dez. 2015.2 Disponível em http://tools.folha.com.br/print?site=emcimadahora\&url=http://www1.folha.uol.com.br/poder/2015/12/1718593manifestacao-anti-dilma-em-sp-reuniu-403-mil-pessoas-mostra-datafolha.shtml. Acessado em 31 jan.2018. 
Hegemonia, destacando-se: a) Movimento Brasil Livre; b) Revoltados Online; e, c) Vem Para Rua; articulados em torno de partidos políticos importantes do país, como PSDB-DEMPMDB, bem como das organizações empresariais brasileiras, como FIESP e a capacidade de difusão das corporações que monopolizam os meios de comunicação no Brasil, constituiu-se um vigoroso movimento conservador de contestação social, como forma de dar sustentabilidade ao Golpe de Estado em marcha.

Em um cenário de emergência de um novo sujeito na arena política, as corporações que monopolizavam os meios de comunicação no Brasil, trataram de reeditar o pacto subterrâneo e promíscuo com o Judiciário e órgãos de controle estatais, que haviam estabelecido em 2005, em torno da Ação Penal 470, como forma de se eleger e definir um inimigo comum a ser combatido e expulso das instituições políticas brasileiras, via espetacularização dos processos conduzidos pelo Judiciário e órgãos de controle, bem como pela ação hollywoodiana de uma Polícia Federal claramente partidária e de oposição ao governo, mediada por conduções coercitivas arbitrárias, prisões preventivas ilegais e sem tempo definido; todas as ações sustentadas em delações premiadas ${ }^{55}$ frágeis e pouco consistentes do ponto de vista jurídico, a partir das quais selecionava-se partes isoladas para serem vazadas e difundidas pela imprensa. Tudo milimetricamente planejado, filmado e transmitido em tempo real, como forma de consubstanciar o discurso da corrupção generalizada no Estado brasileiro e que, portanto, necessitava ser combatido a todo custo, inclusive ao custo dos direitos e princípios democráticos fundamentais que regem o Estado de Direito. Tratava-se de acionar os instrumentos do exclusivismo político, como forma de aniquilamento moral e político das principais lideranças do Partido dos Trabalhadores, bem como das empresas que lhes deram sustentação político-governamental. Ou seja, nem mesmo aquela representação e participação subalterna das classes trabalhadoras exercida pelo Partido dos Trabalhadores, ao longo de seus treze anos de governo, não eram mais admitidos. O Golpe de Estado de 2016 encerrava um longo período de concessões e abriria um drástico período de restauração.

\section{Considerações provisórias.}

O cenário de incertezas, a realidade objetiva e o movimento histórico, impuseram ao Brasil o Estado de Exceção como desdobramento objetivo da crise mundial de 2008, na e a partir da qual se observa a tentativa de se governar pela aparente garantia do ordenamento

55 PRESIDÊNCIA DA REPÚBLICA. Lei $\mathrm{n}^{\circ}$ 12.850, de 02 de agosto de 2013. Disponível em: http://www.planalto.gov.br/ccivil_03/_ato2011-2014/2013/lei/112850.htm. Acessado em 07 jan. 2018. 
jurídico-político constitucional, entretanto, a partir de princípios que se colocam "fora" e/ou "acima" da própria constitucionalidade, estabelecendo-se um ordenamento jurídico-político de exceção, que se coloca "fora" e "acima" da Constituição existente. Trata-se da institucionalização indireta e da governança pela via de regras excepcionais, que como resultado direto aprofundou a crise, alterou a dinâmica da luta de classes e abriu um cenário de incertezas jurídico-políticas, que podem caminhar em direção à desobediência civil generalizada, inclusive no âmbito da institucionalidade, e, consequentemente, no aprofundamento progressivo do Estado de Exceção. Apesar do cenário de incertezas, os caminhos da democracia, hoje, no Brasil, encontram-se nas mãos das classes trabalhadoras e demais classes subalternas, na medida em que consiga impor resistência ao Golpe de Estado, pode-se constituir um movimento ascendente de abertura progressiva do regime e de democratização do país. Todavia, na medida em que não consiga alterar a correlação de forças e forçar um movimento reverso, as classes dominantes, que ora encontra-se em uma luta intestina pelo controle do Estado e pela pequena parte das riquezas deixadas como migalhas pelo capital-imperialismo, conduzirá o Estado brasileiro ao fechamento progressivo do regime e ao aprofundamento do Estado de Exceção. Portanto, no atual cenário catastrófico, no qual se encontra o Brasil, o que ameaça o destino do país não é propriamente a capacidade de organização e mobilização da classe trabalhadora, mas a luta intestina intra burguesa, na e a partir da qual os interesses particulares das frações de classes dominantes ameaçam a frágil institucionalidade liberal-burguesa corporificada na forma do Estado e cuja substância universal é o capital.

\section{Referências}

AMATO, Fábio; PASSARINHO, Nathalia. Entenda os principais pontos da MP dos portos aprovada pelo Congresso. Publicada em 16 mai. 2013. Disponível em http://g1.globo.com/politica/noticia/2013/05/entenda-os-principais-pontos-da-mp-dos-portosaprovada-pelo-congresso.html Acesso em 10 mar. 2018.

BITENCOURT, Cezar Roberto. A teoria do domínio do fato e a autoria colateral. Publicado em 18 nov. 2012. Disponível em: https://www.conjur.com.br/2012-nov-18/cezarbitencourt-teoria-dominio-fato-autoria-colateral Acessado em 07 jan. 2018.

BOBBIO, Norberto. O Futuro da Democracia: uma defesa das regras do jogo. Trad. Marco Aurélio Nogueira. - Rio de Janeiro: Paz e Terra, 1986.

BONFANTI, Cristiane; SIMÃO, Edna. Meirelles diz que política econômica de Lula foi positiva para o país. Publicado em 10 mar. 2017. Disponível em: http://www.valor.com.br/politica/4895170/meirelles-diz-que-politica-economica-de-lula-foipositiva-para-o-pais Acessado em 07 jan. 2018. 
CALDEIRA, João Paulo: Wikileaks revela treinamento de Moro nos EUA. Publicado em 05 jul. 2016. Disponível em: https://jornalggn.com.br/noticia/wikileaks-revela-treinamentode-moro-nos-eua Acessado em 07 jan. 2018.

CALGARO, Fernanda; MODZELESKI, Alessandra; CARAM, Bernardo. Por 251 votos a 233, Câmara rejeita enviar ao STF segunda denúncia contra Temer. Publicado em 25 out. 2017. Disponível em https://g1.globo.com/politica/noticia/segunda-denuncia-contratemer.ghtml Acessado em 09 mar. 2018.

CÂMARA DOS DEPUTADOS. Publicado em 22 abr. 2014. Disponível em: http://www2.camara.leg.br/camaranoticias/radio/materias/REPORTAGEMESPECIAL/466301-DIREITAS-JA-REJEICAO-DA-EMENDA-DANTE-DE-OLIVEIRAMARCA-A-HISTORIA-DO-PAIS-BLOCO-1.html Acessado em 07 jan. 2018.

CARAM, Bernardo; MODZELESKI, Alessandra; GARCIA, Gustavo; CALGARO, Fernanda. Publicado em 02 ago. 2017. Disponível em https://g1.globo.com/politica/noticia/votacaodenuncia-temer-camara.ghtml Acessado em 09 mar. 2018.

CARVAlHO, Laura. A PEC 241 pode prolongar a crise. Publicado em 13 out. 2016. Disponível em: http://tools.folha.com.br/print?site=emcimadahora\&url=http://www1.folha.uol.com.br/coluna s/laura-carvalho/2016/10/1822278-pec-241-pode-prolongar-a-crise.shtml Acessado em 07 jan. 2018.

CASTRO, Jorge Abrahão de. MODESTO, Lúcia (Orgs.) Bolsa família 2003-2010: avanços e desafios. Brasília: Ipea, 2010.

CASTRO, José Roberto. As commodities e seu impacto na economia brasileira. Publicado em 31 mar. 2016. Disponível em https://www.nexojornal.com.br/explicado/2016/03/31/Ascommodities-e-seu-impacto-na-economia-do-Brasil Acessado em 07 jan. 2018.

COLON, Leandro. PMDB aprova participação no governo de coalizão de Lula. Publicado em 30 nov. 2006. Disponível em http://g1.globo.com/Noticias/Politica/0,AA1370004$\underline{5601,00-}$

PMDB+APROVA+PARTICIPACAO+NO+GOVERNO+DE+COALIZAO+DE+LULA.html Acesso em 25 jan. 2018.

COUTINHO, Mateus; GINI, Rodrigo. Azeredo é condenado a 20 anos de prisão por mensalão tucano. Publicado em: $16 \mathrm{dez}$ 2015. Disponível em: http://politica.estadao.com.br/blogs/fausto-macedo/azeredo-e-condenado-a-20-anos-de-prisaopor-mensalao-tucano/ Acesso em: 19 nov 2017.

DATAFOLHA. Acima das expectativas, Lula encerra mandato com melhor avaliação da história. Publicado em 20 dez. 2010. Disponível em http://datafolha.folha.uol.com.br/opiniaopublica/2010/12/1211078-acima-das-expectativaslula-encerra-mandato-com-melhor-avaliacao-da-historia.shtml Acessado em 08 jan. 2018. 
DIAS, Guilherme Soares. Número de greves em 2011 foi o maior desde 1997, diz DIEESE. Publicado em 29 nov. 2012. Disponível em http://www.valor.com.br/brasil/2922634/numerode-greves-em-2011-foi-o-maior-desde-1997-diz-dieese Acessado em 04 mar. 2018.

EBC TV BRASIL. Jurista defende que o monopólio dos meios de comunicação é uma ameaça a democracia. Publicado em 03 fev. 2015. Disponivel em: http://tvbrasil.ebc.com.br/vertv/post/jurista-defende-que-o-monopolio-sobre-os-meios-decomunicacao-e-uma-ameaca-a-democracia Acessado em 07 jan. 2018.

ÉPOCA. Documento do SNI apontou relação de Temer com o jogo do bicho. Publicado em 13 mai. 2016. Disponível em https://epoca.globo.com/tempo/noticia/2016/05/documentodo-sni-apontou-relacao-de-temer-com-o-jogo-do-bicho.html Acessado em 09 mar. 2018.

FERNANDES, André de Godoy. Meios de comunicação social no Brasil: promoção do pluralismo, direito concorrencial e regulação. Publicado em jan. 2009. Disponível em http://www.nevusp.org/downloads/down147.pdf Acessado em 07 jan. 2018.

FERNANDES, Florestan. Sociedade de classes e subdesenvolvimento. Rio de Janeiro: Zahar, 1975 [1968].

Mudanças sociais no Brasil. São Paulo: Difel, 1960.

A revolução burguesa no Brasil. São Paulo: Globo, 2006 [1975].

A sociologia numa era de revolução social. Rio de Janeiro: Zahar, 1976, 2.a ed.

Capitalismo dependente e classes sociais na América Latina. Rio de Janeiro: Zahar, 1981, 3.a ed. [1973].

FOLHA DE SÃO PAULO. Leia íntegra da Carta de Lula para acalmar o mercado financeiro. Publicado em 24 jun. 2002. Disponível em http://www1.folha.uol.com.br/folha/brasil/ult96u33908.shtml Acesso em 11 mar. 2018.

FOLHA DE SÃO PAULO. Ciro afirma que governo FHC "quebrou" o Brasil três vezes. Publicado em 30 nov. 2004. Disponível em http://politica.estadao.com.br/noticias/geral,ciroafirma-que-governo-fhc-quebrou-o-brasil-tres-vezes,20041130p33184 Acessado em 07 jan. 2018.

FOLHA DE SÃO PAULO. Entrevista Rudá Ricci: inclusão na era Lula deixa bombarelógio para Dilma desativar. Publicada em 21 fev. 2011. Disponível em http://www1.folha.uol.com.br/fsp/poder/po2102201107.htm Acessado em 07 jan. 2018.

FOLHA DE SÃO PAULO. Jefferson denuncia mesada paga pelo tesoureiro do PT. $\begin{array}{llllll}\text { Publicado em } & 06 & \text { jun. } & 2005 . & \text { Disponível } & \text { em }\end{array}$ http://www1.folha.uol.com.br/folha/brasil/ult96u69402.shtml Acessado em 31 jan. 2018.

FOLHA DE SÃO PAULO. Manifestações anti-Dilma reuniu 40,3 mil pessoas mostra Datafolha. Publicado em 13 dez. 2015. Disponível em http://tools.folha.com.br/print?site=emcimadahora\&url=http://www1.folha.uol.com.br/poder/ 
2015/12/1718593-manifestacao-anti-dilma-em-sp-reuniu-403-mil-pessoas-mostradatafolha.shtml Acessado em 31 jan.2018.

FOLHA DE SÃO PAULO. Publicado em 19 dez. 2017. Disponível em http://www1.folha.uol.com.br/poder/2017/12/1944795-aprovacao-ao-governo-temer-oscilade-3-para-6-indica-ibope.shtml Acessado em 09 mar. 2018.

FONSECA, Francisco. As três crises do governo Dilma. Publicada em 14 jul. 2015. Disponivel em: https://www.cartamaior.com.br/?/Editoria/Politica/As-tres-crises-do-governoDilma/4/33990 Acessado em 07 jan. 2018.

GRAMSCI, Antonio. Os cadernos do cárcere. Os intelectuais. O princípio educativo. Jornalismo. (vol.2); Trad. Carlos Nelson Coutinho. $3^{\mathrm{a}}$ ed. - Rio de Janeiro: Civilização Brasileira, 2004.

Os cadernos do cárcere. Maquiavel. Notas sobre o Estado e a política. (vol.3); Trad. Carlos Nelson Coutinho, Luiz Sérgio Henrique, Marco Aurélio Nogueira. - Rio de Janeiro: Civilização Brasileira, 2007.

G1. Entenda os protestos em SP, contra o aumento das tarifas dos transportes. Publicado em 11 jun. 2013. Disponível em http://g1.globo.com/sao-paulo/noticia/2013/06/entenda-osprotestos-em-sp-contra-aumento-das-tarifas-do-transporte.html Acessado em 09 mar. 2018.

Protestos contra a abertura da Copa deixam feridos e detidos em SP. Publicado em 12 junh. 2014. Disponível em http://g1.globo.com/sao-paulo/noticia/2014/06/protestoscontra-abertura-da-copa-deixam-feridos-e-detidos-em-sp.html Acesso em 04 marc. 2018.

Réu no mensalão do PSDB mineiro, o deputado Eduardo Azeredo renuncia. Publicado em 19 fev. 2014. Disponível em http://g1.globo.com/jornalnacional/noticia/2014/02/reu-no-mensalao-do-psdb-mineiro-deputado-eduardo-azevedorenuncia.html Acessado em 08 jan. 2018.

GARCIA, Janaina. Frei Betto: "inquilino no governo, PT tomou chega para lado dona da casa". Publicado em 19 nov. 2016. Disponível em https://noticias.uol.com.br/politica/ultimasnoticias/2016/11/19/frei-betto-pt-tem-que-descer-do-salto-e-calcar-sandalias-dahumildade.htm Acessado em 07 jan. 2018.

JORNAL BRASIL 247. Publicado em 28 mai. 2015. Disponível em: https://www.brasil247.com/pt/247/poder/182792/Reelei\%C3\%A7\%C3\%A3o-que-custoumais-caro-ao-Pa\%C3\%ADs-foi-a-de-FHC.htm Acessado em 07 jan. 2018.

JORNAL GGN. Publicado em 20 out. 2014. Disponível em: https://jornalggn.com.br/noticia/provas-da-compra-votos-pela-reeleicao-de-fhc-eram-cabaisconta-jornalista Acessado em 07 jan. 2018.

KERCHE, Fábio. Autonomia e Discricionariedade do Ministério Público no Brasil. Publicado em 2007. Disponível em: http://www.scielo.br/pdf/dados/v50n2/a02v50n2 Acessado em 07 jan. 2018. 
LADEIRA, Pedro. Citados no mensalão tucano se beneficiam de prescrições. Publicado em $30 \quad$ jul. $\quad 2014 . \quad$ Disponível $\quad$ em http://tools.folha.com.br/print?site=emcimadahora\&url=http://www1.folha.uol.com.br/poder/ 2017/06/1893632-citados-no-mensalao-tucano-se-beneficiam-de-prescricoes.shtml Acessado em 08 jan. 2018.

LONDRES, Mariana. Moro teria até $67,8 \%$ dos votos para presidente, diz pesquisa. Publicada em 10 mar. 2016. Disponível em: https://noticias.r7.com/brasil/se-eleicao-fossehoje-juiz-sergio-moro-teria-ate-678-dos-votos-para-presidente-diz-pesquisa-10032016 Acessado em 08 jan. 2018.

LOSURDO, Domenico. Democracia ou Bonapartismo: triunfo e decadência do sufrágio universal. Trad. Luiz Sérgio Henriques. - Rio de Janeiro: UFRJ/São Paulo: UNESP, 2004.

MANNHEIN, Karl. Ideologia e Utopia. Rio de Janeiro: Globo, 1956.

MACHADO, Ivan Carlos Novaes. Publicado em nov. 1997. Disponível em: https://jus.com.br/artigos/1509/inconstitucionalidade-da-emenda-da-reeleicao Acessado em 07 jan. 2018.

MANIN, Bernard. The principles of representative government. Cambridge: Cambridge University Press, 1997.

MARSHALL, Thomas Humprey. Citizenship and social class and other essays. Cambridge: CUP, 1950.

MARX, KARL. A ideologia alemã. Trad. Rubens Enderle; Nélio Schneider; Luciano Cavini Martorano. São Paulo: Boitempo, 2007.

2004.

Manuscritos econômicos filosóficos. Trad. Jesus Ranieri. São Paulo: Boitempo, Crítica da filosofia do direito de Hegel. Trad. Rubens Enderle e Leonardo de Deus. São Paulo: Boitempo, 2005.

. Sobre a questão judaica. Trad. Nélio Schneider. São Paulo: Boitempo, 2010.

2011a.

O 18 brumário de Luís Bonaparte. Trad. Nélio Schneider. São Paulo: Boitempo,

MAZZEO, Antônio Carlos. Estado e Burguesia no Brasil: origens da autocracia burguesa. São Paulo: Boitempo, 2015.

MICHELS, Robert. Os Partidos Políticos. Trad. Hamilton Trevisan. São Paulo: Senzala, [19].

MILLS, C. Wright. A elite do poder. Rio de Janeiro: Zahar, 1981.

MENDONÇA, Ricardo. Joaquim Barbosa é o $2^{\circ}$ voto mais influente da eleição, diz Datafolha. Publicado em 06 jun. 2014. Disponível em 
http://www1.folha.uol.com.br/poder/2014/06/1465888-joaquim-barbosa-e-o-segundo-votomais-influente-da-eleicao.shtml Acessado em 08 jan. 2018.

MORAIS, Lecio; SAAD-FILHO, Alfredo. Da economia política à política econômica: o novo-desenvolvimentismo e o governo Lula. Publicado em dez. 2011. Disponível em http://www.scielo.br/scielo.php?script=sci_arttext\&pid=S0101-31572011000400001

Acessado em 07 jan. 2018.

NEME, Cristina. A instituição policial na ordem democrática: o caso da Polícia Militar do Estado de São Paulo. Publicado em: dez. 1999. Disponível em: http://www.nevusp.org/downloads/down147.pdf Acessado em 07 jan. 2018.

NOGUEIRA, Claudio; GÓES, Bruno; PIMENTEL, Leonardo; ALLEMAND, Marcio; SOARES, Rafael. José Dirceu é condenado por corrupção ativa por 8 a 2. Publicado em 10 out. 2012. Disponível em: https://oglobo.globo.com/brasil/jose-dirceu-condenado-porcorrupcao-ativa-pelo-placar-de-8-2-6362347 Acessado em 07 jan. 2018.

O GLOBO. O Brasil foi às ruas em junho de 2013. Publicado em 16 mai. 2014. Disponível em http://acervo.oglobo.globo.com/fatos-historicos/o-brasil-foi-as-ruas-em-junho-de-201312500090 Acessado em 04 mar. 2018.

OLIVEIRA, Eduardo de Figueiredo Santos Barbarela. Presidencialismo de coalizão: o jeito brasileiro de governar. Revista Habitus: Revista da Graduação em Ciências Sociais do IFCS/UFRJ, Rio de Janeiro, v. 12, n. 2, p. 70-79, dezembro. 2014. Semestral. Disponível em: https://revistas.ufrj.br/index.php/habitus/article/viewFile/11438/8388 Acesso em: 07 jan. 2018.

PEREIRA, Joelma. Joaquim Barbosa não descarta presidência em 2018 e vê repúdio as maiores siglas nas eleições. Publicado em 21 nov. 2017. Disponivel em: http://congressoemfoco.uol.com.br/noticias/joaquim-barbosa-nao-descarta-disputarpresidencia-em-2018-e-ve-repudio-as-maiores-siglas-nas-eleicoes/ Acessado em 08 jan. 2018.

POULANTZAS, Nicos. Pouvoir politique et classes sociales. Petite collection v.01 e 02. Paris: François Maspero, 1972.

PRESIDÊNCIA DA REPÚBLICA. Emenda Constitucional n⿳16, de 04 de junho de 1997. Disponível em http://www.planalto.gov.br/ccivil_03/constituicao/emendas/emc/emc16.htm Acessado em 13 jan. 2018.

Lei Complementar $\mathbf{n}^{0}$ 101, de 04 de maio de 2000. Disponível em http://www.planalto.gov.br/ccivil_03/Leis/LCP/Lcp101.htm Acessado em 09 mar. 2018.

Lei $\mathrm{n}^{\mathrm{0}}$ 12.850, de 02 de agosto de 2013. Disponível em: http://www.planalto.gov.br/ccivil_03/_ato2011-2014/2013/lei/112850.htm Acessado em 07 jan. 2018.

QUEIROS, Luiz de. Com PT, PF realizou 50 vezes mais operações do que com FHC. Publicado em 20 jul. 2014. Disponível em: https://jornalggn.com.br/noticia/com-pt-pfrealizou-50-vezes-mais-operacoes-do-que-com-fhc Acessado em 07 jan. 2018. 
R7. TCU Contabiliza R\$ 25 bilhões de gastos com a Copa do Mundo. Publicado em 04 dez. 2014. Disponível em https://noticias.r7.com/brasil/tcu-contabiliza-r-255-bilhoes-degastos-com-a-copa-do-mundo-04122014 Acessado em 04 mar. 2018.

REVISTA FORUM. Paulo Moreira Leite: condenado sem domínio nem fato. Publicado em 13 nov. $2012 . \quad$ Disponível https://www.revistaforum.com.br/mariafro/2012/11/13/paulo-moreira-leite-condenado-semdominio-nem-fato/ Acessado em 09 mar. 2018.

REVISTA GGN. Moro, Lava Jato e interesses dos Estados Unidos. Publicado em 24 jun. 2017. Disponível em: https://jornalggn.com.br/noticia/moro-lava-jato-e-interesses-dos-eua Acessado em 07 jan. 2018.

ROMA, Celso. A institucionalização do PSDB entre 1988 e 1999. Publicado em jun. 2002. Disponível em: http://www.redalyc.org/html/107/10704906/ Acessado em 07 jan. 2018.

SAMPAIO Jr., Plínio de Arruda (Org.). Jornadas de Junho: a revolta popular em debate.São Paulo: ICP, 2014.

SECCO, Lincoln. História do PT 1978-2010. Cotia-SP: Ateliê Editorial, 2011.

SINGER, André. Raízes sociais e ideológicas do lulismo. Novos Estudos. São Paulo, nº 85, p. 83-102, dez. de 2009.

SILVA, Luiz Fernando da. A política externa estadunidense no atual quadro político sulamericano. Publicado em 17 jan. 2011. Disponível em: http://www.scielo.org.mx/scielo.php?script=sci_arttext\&pid=S1665-85742011000100005

Acessado em 07 jan. 2018.

SILVA, Marcelo Lira. O projeto de governança do Partido dos Trabalhadores e sua identidade com o projeto de modernização conservadora (2003-2015). Publicado em 24 ago. 2015.2 Disponível em: http://www.niepmarx.blog.br/MM2015/anais2015/mc68/Tc684.pdf Acessado em 07 jan. 2018.

SINGER, André. Os sentidos do lulismo: reforma gradual e pacto conservador.São Paulo: Companhia das Letras, 2012.

SOUEN, Jacqueline Aslan. A política do salário mínimo no Governo Lula. Publicado em 2013.

http://repositorio.unicamp.br/bitstream/REPOSIP/286108/1/Souen_JacquelineAslan_M.pdf Acessado em 07 jan. 2018. 